\title{
ADAKAH PENGARUH PERTUMBUHAN EKONOMI TERHADAP PENDAPATAN ASLI DAERAH?
}

\author{
Faishal Fadly ${ }^{1}$ \\ ${ }^{1}$ Fakultas Ekonomi dan Bisnis Universitas Brawijaya \\ Email: Faishalfadly@ub.ac.id
}

\begin{abstract}
The implementation of regional autonomy resulted in each region to be able to manage their finances independently. This is one way the central government to remove the dependency of local governments to the central government. Thus requiring local governments to explore the sources of local revenue in order to finance regional development. In an effort to increase local revenues derived from the PAD is determined by economic factors or economic potential which has the prospect to be developed for each area. While the economic progress of a region heavily dependent on the development efforts undertaken by the government in providing public facilities to support economic activity. so it needs to be studied further economic growth in East Java, which increased from year to year, is also accompanied by an increase in revenue (PAD) as one source of income in financing regional development. The result indicates the role of the revenue $(P A D)$ in the Regional Budget (APBD) of East Java Province indicates that there is still very small, with an average of $15.47 \%$ of the total revenue budget. This means that the level of dependence of local governments on the central government is still high. Although the results of regional revenue projections indicate that component has been great in their contribution of the reception area, which amounted to $69.52 \%$. Using the ordinary least squre method, the result of regression correlation are insignificant. This means that the regional gross domestic product does not have an effect on revenue of East Java Province. If an increase or decrease in regional gross domestic product will not increase or decrease revenue amount. This means that there is no significant relationship between economic growths towards the reception of the revenue
\end{abstract}

Keywords: economic growth, revenues (PAD), Regional Budget (APBD), Gross Domestic Product (GDP)

JEL Classification: C22, H71, O38

\section{PENDAHULUAN}

Pemberian otonomi dan tanggung jawab yang lebih besar dari pemerintah pusat kepada pemerintah daerah pada prinsipnya dimaksudkan untuk membantu pemerintah pusat dalam penyelenggaraan pemerintahan pada umumnya (Davey, 1988 dan Hirawan, 1991). Di samping itu, tujuan lain dari pemberian otonomi daerah adalah untuk mengurangi ketergantungan pemerintah daerah terhadap pemerintah pu- sat terutama dalam masalah keuangan, sehingga daerah diharapkan mampu membiayai keuangannya secara mandiri. Salah satu yang menjadi perhatian pemerintah daerah adalah dalam pegelolaan penerimaan yang berasal dari daerah sendiri.

Usaha untuk menggali sumber-sumber Pendapatan Asli Daerah (PAD) sebagai salah satu sumber dalam pembiayaan penyelenggaraan kewenangan harus didukung oleh potensi ekonomi yang dimiliki dae- 
rah sebagai basis PAD. Hal ini disebabkan karena kemampuan masyarakat untuk membayar pajak dan retribusi kepada daerah sangat tergantung kepada aktifitas ekonomi yang mereka lakukan. Semakin tinggi aktifitas ekonomi yang dilakukan, akan meningkatkan pendapatan yang mereka terima dan seiring dengan hal itu usaha daerah untuk meningkatkan PAD melalui pajak daerah dan retribusi daerah dapat ditingkatkan.

Peranan Pendapatan Asli daerah (PAD) di dalam penerimaan Pemerintah Daerah Tingkat I seluruh Indonesia relatif sangat kecil untuk dapat membiayai pembangunan daerah. Sedangkan menurut prinsip otonomi daerah penyelengaraan pemerintahan dan pembangunan daerah secara bertahap akan semakin dilimpahkan pada daerah. Dengan semakin besarnya kewenangan pemerintah pusat yang diberikan kepada pemerintah daerah maka peranan keuangan pemerintah daerah akan semakin penting karena daerah dituntut untuk dapat lebih aktif lagi dalam memobilisasi dananya sendiri (Bachtiar, 1992). Usaha pemerintah untuk mengembangkan dan meningkatkan peranan dan kemampuan daerah dalam bidang ekonomi dan pengelolaan keuangan daerah ini, sebenarnya telah dicanangkan dan dimulai sejak Pelita I (Insunkindro, 1994).

Keuangan daerah merupakan salah satu dasar kriteria untuk mengetahui secara nyata kemampuan daerah dalam mengurus rumah tangga sendiri (Kaho, 1995). Hal ini mengandung pengertian bahwa secara otomatis Pemerintah Daerah juga harus melaksanakan keuangan daerah. Oleh karena itu, perhatian harus dipusatkan pada usaha - usaha untuk memperkuat mata rantai kegiatan yang dapat membangkit dan meluas dengan hubungan keterkaitan yang dimaksud.

Jaya (1999) menyatakan bahwa sumber pembiayaan pembangunan yang penting untuk diperhatikan adalah penerimaan daerah sendiri, karena sumber inilah yang merupakan wujud partisipasi langsung masyarakat suatu daerah dalam mendukung proses pembangunan. Penerimaan daerah sendiri yang merupakan wujud partisipasi masyarakat dalam bentuk pembayaran pajak dan retribusi daerah, harus mampu mendorong pertumbuhan ekonomi daerah, yang pada akhirnya akan menaikkan pendapatan daerah.

Pelaksanaan otonomi daerah di Indonesia dipandang sebagai suatu strategi yang memiliki tujuan ganda. Pertama, pemberian otonomi daerah merupakan suatu strategi untuk merespon tuntutan masyarakat daerah terhadap tiga permasalahan utama, yaitu sharing of power, distribution of income, dan kemandirian sistem manajemen di daerah. Ke$d u a$, otonomi daerah dimaksudkan sebagai strategi untuk memperkuat perekonomian daerah dalam rangka memperkokoh perekonomian nasional untuk menghadapi era perdagangan bebas (Mardiasmo, 2002).

Sumber keuangan dibutuhkan agar tugas pemerintahan yang diamanatkan oleh otonomi daerah dapat dilaksanakan dengan efisien dan efektif. Masalah keuangan daerah merupakan permasalahan yang esensial dan mendasar, termasuk bagi Pemerintah Provinsi Jawa Timur. Dalam memberikan pelayanan kepada masyarakat, maupun dalam rangka pembangunan daerah Pemerintah Provinsi Jawa Timur memerlukan dana operasional.

Salah satu indikator turunnya ketergantungan daerah terhadap pemerintah pusat adalah, meningkatkan kemampuan daerah dalam 
menggali sumber - sumber pendapatan daerah, baik secara intensifikasi maupun ekstensifikasi sehingga daerah memiliki dana yang signifikan dalam rangka membiayai pembangunan daerah guna meningkatkan pola kesejahteraan masyarakat. Upaya meningkatkan penerimaan daerah yang bersumber dari PAD sangat ditentukan oleh faktor ekonomi atau potensi ekonomi yang memiliki prospek untuk dikembangkan bagi setiap daerah. Sedangkan kemajuan ekonomi suatu daerah sangat tergantunng upaya pembangunan yang dilakukan oleh pemerintah dalam menyediakan fasilitas publik guna mendukung aktifitas ekonomi.

Gambar 1 Pendapatan Daerah Provinsi Jawa Timur Tahun 2006 - 2015 (Miliar Rupiah)

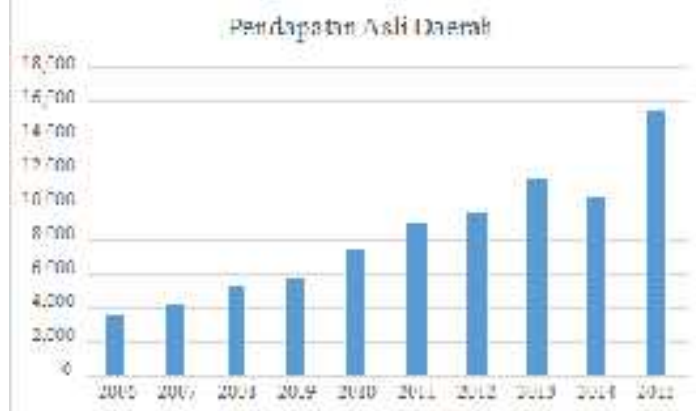

Sumber : DJPK, 2015

Berdasarkan data menurut Dirjen Perimbangan Keuangan di atas dapat diketahui bahwa nilai Pendapatan Asli Daerah provinsi Jawa Timur dari tahun 2006 hingga tahun 2015 mengalami tren kecenderungan yang meningkat. Peningkatan paling signifikan terjadi pada tahun 2015. Hal terebut menunjukan kemandirian Provinsi Jawa timur untuk mencari sumber pendapatannya di luar dana transfer dari pemerintah pusat.

Usaha untuk menggali sumber-sumber pendapatan daerah, mengalami berbagai kendala, baik dari sgi keterbatasan sumber dana itu sendiri maupun dari segi kemampuan dan sistem pengelolaan serta proses administrasinya. Perkembangan dalam proses pembangunan daerah berkaitan dengan perkembangan di sektor pendapatan daerah ini, yang minimal harus dapat menimbangi langkah- langkah pemerintah daerah dalam percepatan pembangunan di daerahnya.

Pelaksanaan otonomi daerah merupakan pola dan proses yang memerlukan keterlibatan segenap unsur dan lapisan masyarakat, serta memberikan kekuasaan bagi pemerintah daerah dalam melakukan pengelolaan keuangan daerah sehingga peran pemerintah adalah sebagai katalisator dan fasilitator karena pihak pemerintah lah yang lebih mengetahui sasaran dan tujuan pembangunan yang akan dicapai. Sebagai katalisator dan fasilitator tentunya membutuhkan berbagai sarana dan fasilitas pendukung dalam rangka terlaksananya pembangunan secara berkesinambungan.

Sampai saat ini berbagai kebijakan telah diambil oleh pemerintah untuk mengembangkan dan meningkatkan kemampuan daerah di bidang keuangan daerah, karena aspek keuangan daerah menjadi sesuatu yang penting, sebab dalam proses penyelenggarakan pemerintahan dan pembangunan daerah dibutuhkan dana atau biaya yang cukup besar.

Gambar 2 Pertumbuhan Ekonomi Jawa Timur 2001 - 2015 (Persentase)

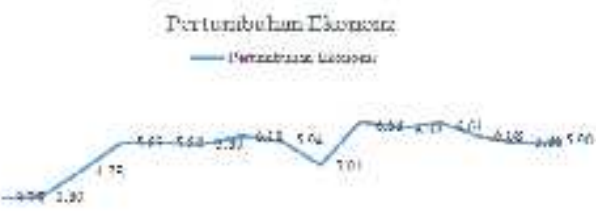

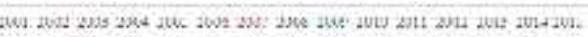
Sumber : BPS Jawa Timur, 2006 
Berdasarkan gambar performa Pertumbuhan Ekonomi provinsi Jawa Timur di atas dapat diketahui bahwa pertumbuhan ekonomi di provinsi Jawa Timur memiliki tren kecenderungan yang berfluktuasi. Adanya tren ke-cenderungan meningkat terjadi dari tahun 2001 hingga 2007. Sedangkan tahun 2009 mengalami penurunan yang signifikan akibat dampak dari krisis keuangan internasional. Tahun 2011 kembali tumbuh walaupun memiliki kecenderungan yang menurun tetapi tidak signifikan. Apabila dihubungkan dengan tren kecenderungan dari Pendapatan Asli Daerah Provinsi Jawa Timur pada gambar $1 \mathrm{di}$ atas maka dapat dilihat ada kemiripan tren dengan gambar 2 pertumbuhan ekonomi provinsi Jawa Timur.

Sumber Pendapatan Asli Daerah Provinsi Jawa Timur yang paling besar adalah dari Pendapatan Pajak. Sedangkan pajak di himpun dari seluruh masyarakat di provinsi Jawa Timur. Apabila ada kenaikan dalam pertumbuhan ekonomi di provinsi Jawa Timur akan menyebabkan kenaikan dalam pembayaran pajak. Hal tersebut dikarenakan pertumbuhan ekonomi memiliki dampak tumbuhnya nilai PDRB di provinsi Jawa Timur. PDRB yang tumbuh memiliki arti semakin berkembangnya perekonomian di provinsi Jawa Timur. Ketika perekonomian tumbuh akan membawa dampak tumbuhnya pajak yang dihimpun akibat tumbuhnya nilai PDRB. Berdasarkan penjelasan tersebut maka perlu dilakukan penelitian tentang kebenaran dari hubungan tersebut.

Pola pertumbuhan ekonomi Provinsi Jawa Timur yang meningkat dari tahun ke tahun, apakah juga dibarengi dengan peningkatan penerimaan Pendapatan Asli Daerah (PAD) sebagai salah salah satu sumber pendapatan dalam pembiayaan pembangunan daerah. Sehingga perlu dilakukan pengkajian lebih lanjut. Maka permasalahan yang dikaji dalam penelitian adalah hubungan antara Pertumbuhan Ekonomi daerah terhadap pertumbuhan Pendapatan Asli Daerah (PAD) Provinsi Jawa Timur.

Dari latar belakang dan permasalahan yang dikemukakan di atas, maka tujuan penelitian ini adalah menganalisis apakah terdapat pola hubungan antara pertumbuhan ekonomi daerah terhadap pertumbuhan Pendapatan Asli Daerah (PAD) daerah Provinsi Jawa Timur.

Hasil penelitian ini diharapkan dapat memberikan sumbangan pikiran dan manfaat yang berarti yaitu : memberikan sumbangan referensi dalam bidang ilmu keuangan khususnya pengelolaan keuangan daerah.

Penelitian ini juga diharapkan memberikan sumbangsih pemikiran bagi daerah, dalam rangka pengelolaan keuangan daerah, serta memperkaya kajian dan melengkapi kajian yang pernah dilakukan sebelumnya tentang keuangan daerah dengan melihat hubungan antara pertumbuhan ekonomi daerah (PD$\mathrm{RB})$ dengan pertumbuhan PAD.

\section{TINJAUAN PUSTAKA DAN HIPOTESIS}

\section{Pendapatan Asli Dareah}

Dalam hubungan antara pemerintah pusat dan pemerintah daerah, Davey (1988) mengemukakan bahwa pendanaan pemerintah daerah terdiri dari alokasi pemerintah pusat, perpajakan, retribusi (charging), pinjaman, dan badan usaha. Dalam perspektif otonomi daerah, PAD menjadi sumber keuangan paling utama selain jenis penerimaan daerah lainnya yang merupakan penjabaran dari Undang-Undang 
Nomor 33 Tahun 2004 tentang Perimbangan Keuangan antara Pusat dan Daerah.

Menurut Undang-undang Nomor 34 Tahun 2000 tentang Perubahan atas Undang-undang Nomor 18 Tahun 1997 tentang Pajak Daerah dan Retribusi Daerah. Pasal 1 ayat 6 , Pajak Daerah yang selanjutnya disebut pajak adalah iuran wajib yang dilakukan oleh orang pribadi atau badan kepada daerah tanpa imbalan langsung yang seimbang, yang dapat dipaksakan berdasarkan perundang-undangan yang berlaku, yang digunakan untuk membiayai penyelenggaraan pemerintahan daerah dan pembangunan daerah.

Sedikit berbeda dengan Pajak Daerah, menurut Kaho (2001) Retribusi Daerah adalah pungutan daerah sebagai pembayaran atas pemakaian jasa atau karena mendapatkan jasa pekerjaan, usaha atau milik daerah bagi yang berkepentingan atau karena jasa yang diberikan oleh daerah. Retribusi daerah dipungut oleh daerah, terdapat pemberian prestasi oleh daerah yang secara langsung dapat ditunjuk, dikenakan kepada siapa saja yang mengenyam jasa yang diberikan oleh daerah.

Menurut Undang-Undang Nomor 34 tahun 2000 tentang Perubahan atas Undang-undang Nomor 18 Tahun 1997 tentang Pajak Daerah dan Retribusi Daerah. Retribusi Daerah merupakan pungutan daerah sebagai pembayaran atas; a) jasa berupa usaha dan pelayanan yang diberikan oleh daerah, baik berbentuk pelayanan umum maupun jasa usaha; b) pemberian izin tertentu berupa pemberian izin kepada orang pribadi dengan maksud pembinaan, pengaturan, pengendalian dan pengawasan atas kegiatan, pemanfaatan, ruang, penggunaan sumber daya alam, barang dan prasana, sarana dan prasarana atau fasilitas tertentu guna melindungi kepentingan umum dan menjaga kelestarian lingkungan. Keduanya merupakan jasa dan pemberian izin yang khusus disediakan dan atau diberikan oleh pemerintah daerah untuk kepentingan orang pribadi atau badan.

\section{Pertumbuhan Ekonomi}

Menurut Kuznets, pertumbuhan ekonomi adalah kenaikan kapasitas dalam jangka panjang dari negara yang bersangkutan untuk menyediakan atau dimungkinkan oleh adanya kemajuan atau penyesuaian berbagai barang ekonomi kepada penduduknya. Kenaikan kapasitas itu sendiri ditentukan atau dimungkinkan oleh adanya kemajuan atau penyesuaian-penyesuaian teknologi, institusional (kelembagaan) dan ideologis terhadap berbagai tuntutan keadaan yang ada (lihat Todaro, 1998).

Pertumbuhan ekonomi secara singkat merupakan proses kenaikan output per kapita dalam jangka panjang (Boediono, 1992). Pengertian ini menekankan pada tiga hal yaitu proses, output per kapita dan jangkapanjang. Proses menggambarkan perkembangan perekonomian dari waktu ke waktu yang lebih bersifat dinamis, output per kapita mengaitkan aspek output total (PDB) dan aspek jumlah penduduk, sedangkan jangka panjang akan menunjukkan pola kecenderungan terhadap perubahan perekonomian dalam jangka waktu tertentu yang didorong oleh proses intern perekonomian (self generating). Pertumbuhan ekonomi juga diartikan secara sederhana sebagai kenaikan output total (PDB) dalam jangka panjang tanpa memandang apakah kenaikan itu lebih kecil atau lebih besar dari laju pertumbuhan penduduk atau ap- 
akah diikuti oleh pertumbuhan struktur perekonomian atau tidak.

Dalam kaitannya dengan pendapatan daerah, Peacok dan Wiseman (1961) dalam teorinya mengenai tentang perkembangan pengeluaran pemerintah yang terbaik berkesimpulan bahwa dalam partumbuhan performa ekonomi menyebabkan pemungutan pajak yang semakin meningkat walaupun tarif pajak tidak berubah dan meningkatnya penerimaan pajak menyebabkan pengeluaran pemerintah juga semakin meningkat(Mangkoesoebroto,1991). Oleh karena itu dalam keadaan normal, meningkatnya GNP menyebabkan adanya penerimaan pemerintah yang semakin besar, begitu juga dengan pengeluaran pemerintah menjadi semakin besar.

Davey (1988) menyatakan bahwa salah satu kriteria untuk menilai potensi pajak daerah adalah elastisitas. Elastisitas dapat dengan mudah diukur dengan membandingkan hasil penerimaan selama beberapa tahun dengan perubahanperubahan dalam indeks harga, penduduk, atau GNP. PDRB merupakan alat ukur pertumbuhan ekonomi yang menggambarkan jumlah nilai produk barang dan jasa akhir yang dihasilkan oleh berbagai unit produksi dalam suatu wilayah atau region pada suatu jangka waktu tertentu. Dari sini dapat di lihat bahwa hubungan elastisitas antara pajak dearah yang diperoleh, dan pertumbuhan ekonomi yang dinilai dari pertumbuhan PDRB per kapita menggambarkan pertumbuhan yang otomatis dari potensi pajak. Dengan kata lain dalam konteks pajak daerah, semakin tinggi PDRB secara otomatis semakin tinggi pula pajak yang diterima daerah.

Brata (2004), dalam penelitiannya tentang komposisi penerimaan pemerintah daerah (Pemda Ti- ngkat I) pertumbuhan ekonomi regional di Indonesia memberikan indikasi adanya disparitas penerimaan Pemda Tingkat I antar provinsi. Disparitas pada komponen-komponen penerimaan tersebut juga tampak kendati tingkat ekonominya seimbang. Adapun dari hasil estimasi ditemukan bahwa tidak seluruh komponen penerimaan Pemda Tingkat I memberikan pengaruh positif terhadap pertumbuhan ekonomi regional yang dilihat dari PBRD per kapita. Selain itu terdapat pula indikasi bahwa komponen penerimaan pemerintah daerah tersebut lebih memiliki hubungan yang kuat dengan PDRB non migas daripada PDRB migas.

\section{Hubungan Antara PDRB dengan Pajak Daerah}

Hubungan antara PDRB dengan pajak daerah merupakan hubungan secara fungsional, karena pajak daerah merupakan fungsi dari PDRB, yaitu dengan meningkatnya PDRB akan menambah penerimaan pemerintah dari pajak daerah. Selanjutnya dengan bertambahnya penerimaan pemerintah akan mendorong peningkatan pelayanan pemerintah kepada masyarakat yang nantinya diharapkan dapat meningkatkan produktivitas masyarakat yang akhirnya dapat meningkatkan partumbuhan ekonomi kembali. Begitu juga sebaliknya dengan meningkatnya pertumbuhan ekonomi dan pendapatan per kapita masyarakat, maka akan mendorong kemampuan masyarakat untuk membayar pajak dan pungutan lainnya.

Berkaitan dengan pajak daerah yang memiliki hubungan positif dengan pertumbuhan ekonomi, $\mathrm{Mu}$ sgrave (1991) menyatakan bahwa ada tiga dasar basis pemungutan pajak pusat dan daerah. Dasar basis pemungutan pajak tersebut meliputi 
pajak daerah maupun pajak pusat yang berbasis pendapatan dan perusahaan (income and corporate), konsumsi (comsumption), dan kekayaan (wealth). Berdasarkan pendapat Fisher tersebut, maka pajak hotel dan restoran, pajak hiburan, pajak reklame serta pajak penerangan jalan dikategorikan pajak daerah yang berbasis konsumsi. Senada dengan pendapat tersebut Devas dkk. (1989) mengemukakan bahwa pajak penerangan jalan adalah konsumsi listrik masyarakat.

Peacock dan Wiseman tahun 1961 menyatakan bahwa perkembangan performa ekonomi menyebabkan pemungutan pajak yang semakin meningkat, dan semakin meningkatnya penerimaan pajak menyebabkan pengeluaran pemerintah juga semakin meningkat (Mangkoesoebroto, 1999). Sehubungan dengan peran pemerintah terhadap pertumbuhan ekonomi, Miller dan Russex (1997), meneliti pengaruh struktur fiskal terhadap pertumbuhan ekonomi pusat dan daerah di Amerika Serikat, mengatakan bahwa, pertama, peningkatan surplus anggaran akan mendorong pertumbuhan ekonomi, bila pengeluaran untuk pendidikan atau transportasi publik dapat ditekan atau coorporate income tax ditingkatkan, kedua, apabila sales tax dan pajak lainnya digunakan untuk transfer payment, maka pertumbuhan ekonomi akan menurun, tapi apabila coorporate income tax digunakan untuk transfer payment maka pertumbuhan ekonomi akan meningkat, ketiga, pajak akan berpengaruh negatif terhadap pertumbuhan ekonomi apabila penerimaan negara digunakan untuk membiayai pendidikan, transportasi publik dan keamanan publik.

\section{Tinjauan Empiris}

Berbagai penelitian mengenai aspek yang berhubungan dengan pengelolaan keuangan daerah telah sering dilakukan oleh para peneliti sebelumnya antara lain seperti : Bachtiar (1992) dalam penelitiannya tentang otonomi dan implikasinya terhadap kemampuan keuangan daerah di Indonesia dengan menggunakan data penerimaan seluruh Daerah Tingkat I Tahun Anggaran 1986/1987 dan 1990/1991, menemukan beberapa fakta. Pertama, bahwa peranan bantuan/sumbangan pemerintah pusat masih sekitar $60 \%$ dalam penerimaan daerah dan PAD meningkat sekitar 24\% (1990/1991), kedua, dari hasil regresi ditemukan bahwa PDRB adalah salah satu faktor yang mempengaruhi besarnya PAD dari suatu daerah. Semakin besar PDRB suatu daerah maka akan semakin tinggi PAD dari daerah yang bersangkutan. Jumlah penduduk adalah juga salah satu faktor yang mempengaruhi besarnya PAD dari suatu daerah, tetapi pengaruh pertambahan jumlah penduduk tidak sebesar pengaruh dari penambahan PDRB.

Kuncoro (1995) menjelaskan pengamatannya pada kenyataan rendahnya PAD sehingga ketergantungan terhadap keuangan pemerintah daerah sangat tinggi terhadap pemerintah pusat. Untuk mengurangi subsidi pemerintah pusat, $\mathrm{Ku}-$ ncoro mengajurkan diberikan otonomi keuangan daerah yang relatif luas sehingga daerah mampu menggali sumber-sumber keuangannya sendiri dan memanfaatkannya secara optimal.

Kifliansyah dalam Halim (2000), penelitian tentang analisis realisasi anggaran pendapatan dan belanja daerah, studi kasus Kabupaten Hulu Sungai Tengah Provinsi Kalimantan Selatan, menemukan fakta bahwa APBD kabupaten se- 
bagian besar dananya masih bersumber dari alokasi pemerintah/instansi yang lebih tinggi (pemerintah pusat dan provinsi) dan kemampuan PAD untuk menopang pengeluaran baik rutin maupun pembangunan (belanja modal) relatif sangat rendah yaitu kurang dari 5\% dari total pengeluaran,sehingga akan terjadi ketergantungan Kabupaten Hulu Sungai Tengah terhadap pemerintah pusat masih sangat tinggi

Berdasarkan tujuan penelitian dan perumusan masalah yang dikemukakan di atas, maka rumusan hipotesis dari penelitian ini adalah: diduga pertumbuhan ekonomi, berpengaruh terhadap penerimaan Pendapatan Asli Daerah (PAD) Provinsi Jawa Timur.

\section{METODE PENELITIAN Data dan Sumber Data}

Data yang digunakan untuk mendukung penulisan adalah data sekunder. Data sekunder adalah data yang diperoleh melalui dokumendokumen resmi serta laporan keuangan berupa data runtut waktu (time series) dari Tahun Anggaran 2000 sampai dengan Tahun Anggaran 2006 dan data Produk Domestik Regional Bruto (PDRB) Provinsi Jawa Timur.

Dengan menggunakan linear teknik interpolasi (Insukindro, 2000), penelitian ini memecah data tahunan dari tahun 2006 sampai 2015 untuk data kuartalan dari tahun 2006 sampai 2015. Jadi dapat mencapai nilai $\mathrm{N}$ minimum. Rumusnya adalah sebagai berikut:

$$
\begin{aligned}
& \text { a- } \left.{ }^{-1} \text { in }{ }^{1, i}, z_{i} \quad \gamma_{1}\right) \\
& 2 L_{1}^{1}+12^{1, j}\left(r_{t}-r_{t-1}\right) \\
& \text { (2) } \left.\frac{1}{4} \text {, w1 } \frac{1,5}{12}\left(r_{t}-\gamma_{t-1}\right)\right]
\end{aligned}
$$$$
\text { (i) } \quad I^{4} \underline{15}-,\left(\gamma_{t}+{ }_{12}\left(\gamma_{t}-\gamma_{t-1}\right)\right]
$$

\section{Model Analisis}

Model Analisis yang digunakan dalam penelitian ini adalah Analisis deskriptif dan kuantitatif. Analisa deskriptif dan kuantitatif diarahkan untuk menganalisis tentang perkembangan perekonomian daerah dan perkembangan pendapatan daerah Provinsi Jawa Timur. Kemudian alat analisis yang digunakan adalah analisis kuantitatif yaitu analisis Ordinary Least Square $(O L S)$. Untuk mengetahui bagaimana pengaruh perkembangan ekonomi terhadap penerimaan PAD digunakan analisis regresi. $\mathrm{PAD}=\mathrm{f}$ (PDRB). Signifikansi model akan diuji dengan $R$ square $\left(R^{2}\right)$, uji t dan uji $F$.

\section{ANALISIS DATA DAN PEM-}

\section{BAHASAN}

\section{Pengaruh Perekonomian Terhadap Pendapatan Asli Daerah}

Untuk melihat pengaruh perkembangan ekonomi terhadap pendapatan asli daerah dilakukan dengan regresi sederhana (simple regression) antara Produk Domestik Regional Bruto (PDRB) sebagai independent variabel dengan Pendapatan Asli Daerah (PAD) sebagai dependent variabel. Sesuai dengan kerangka pemikiran bahwa perkembangan perekonomian akan berpengaruh terhadap peningkatan pendapatan asli daerah. Semakin baik perekonomian atau semakin meningkat nilai tambah yang dihasilkan oleh masing-masing sektor dalam perekonomian maka kemampuan atau potensi masyarakat untuk membayar pajak dan retribusi akan semakin meningkat.

Dari hasil regresi diperoleh $\mathrm{R}$ square sebesar 0.065 berarti peningkatan pendapatan asli daerah dipengaruhi oleh peningkatan nilai 
tambah dalam perekonomian sebesar $6 \%$ yang berarti bahwa performa pertumbuhan ekonomi mempengaruhi pendapatan asli daerah sepenuhnya. Data ini mengindikasikan bahwa dalam perkembangan ekonomi daerah sangat besar pengaruhnya terhadap peningkatan PAD.

Untuk melihat efek dari variabel independen terhadap variabel dependen dalam hal ini pengaruh pembangunan ekonomi untuk meningkatkan pendapatan daerah adalah dari $\mathrm{F}$ dihitung atau $\mathrm{t}$. Dari jumlah hasil regresi diperoleh F sebesar 0, 13 (lebih dari 0000), dan $\mathrm{t} 0,70$ yang tidak memiliki tingkat signifikansi (lebih dari 0000). Dengan demikian dapat dikatakan bahwa pembangunan ekonomi tidak memiliki pengaruh yang signifikan pada peningkatan pendapatan asli daerah di Provinsi Jawa Timur.

Dari hasil regresi adalah koefisien korelasi positif 0,64 berarti bahwa produk domestik regional bruto efek positif pada pendapatan dari Provinsi Jawa Timur. Jika peningkatan produk domestik regional bruto oleh 1 unit akan meningkatkan pendapatan sebesar 0,64 Dapat disimpulkan bahwa perkembangan ekonomi Provinsi Jawa Timur memiliki efek positif pada pendapatan dari Provinsi Jawa Timur. Jika peningkatan perekonomian, pendapatan daerah Provinsi Jawa Timur akan meningkat. Namun, hasil ini tidak dapat digunakan. Karena hasil regresi tidak signifikan.
Hasil estimasi dengan metode OLS

SUMMURV OUTPLT
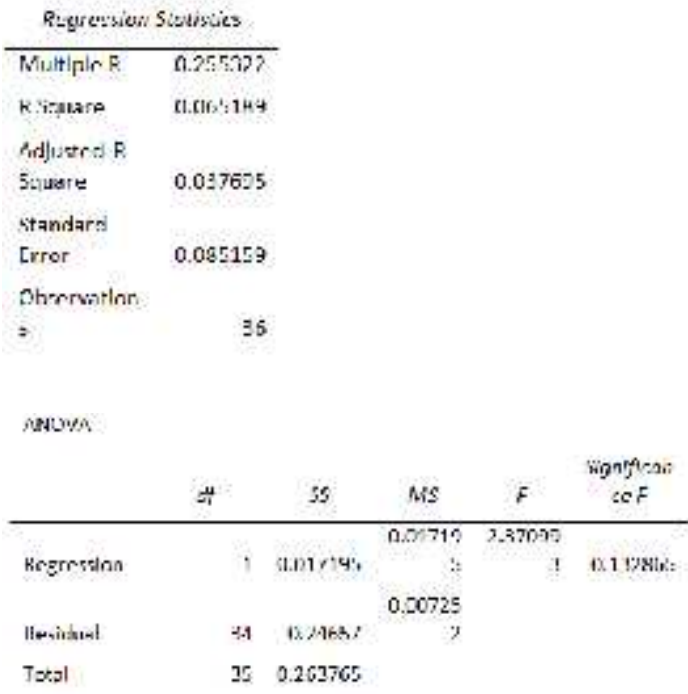

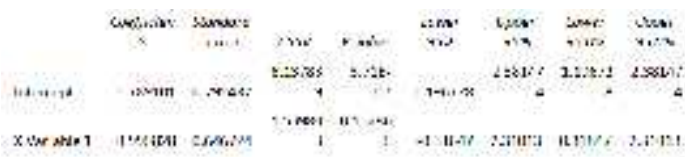

\section{Manajemen Penerimaan PAD di Provinsi Jawa Timur}

Dalam rangka pembiayaan pemerintah daerah yang dibiayai atas dari dan atas beban Anggaran Pendapatan dan Belanja Daerah (APBD) Provinsi Jawa Timur, maka pertama yang menjadi perhatian adalah seberapa besar pendapatan yang diterima oleh daerah. Total realisasi dari pajak daerah pada tahun 2014 mencapai 11,52 trilyun rupiah dan merupakan penyumbang terbesar terhadap Pos Penerimaan Pendapatan Asli Daerah Jawa Timur sebesar 79,75 persen merupakan upaya pemerintah untuk berusaha menggali dan mengembangkan potensi penerimaan daerah khususnya untuk meningkatkan penerimaan PAD. Pada komponen PAD, dari analisis data penerimaan pajak daerah dan retribusi daerah menunjukkan, ternyata kenaikan penerimaan daerah dari pajak daerah 
selama periode analisis lebih tinggi dibandingkan dengan rasio kenaikan penerimaan daerah dari retribusi daerah. Hal ini menunjukkan bahwa masyarakat lebih merasa rela membayar pajak daerah dari pada retribusi daerah yang manfaat atau kontraprestasinya dirasakan langsung oleh wajib pajak.

Hal yang paling menarik untuk dilakukan oleh Pemerintah Daerah Provinsi Jawa Timur dalam rangka untuk mengurangi tingkat ketergantungan keuangan pada Pemerintah Pusat yang pada akhirnya akan mandiri dalam pembiayaan pembangunan adalah adanya suatu aktor stimulator untuk peningkatan PAD. Apabila masih berharap kepada masyarakat tentu tidak akan pernah perolehan PAD melebihi $79,75 \%$ dari total penerimaan daerah. Hal ini dikarenakan kondisi Provinsi Jawa Timur sendiri yang memang memungkinkan untuk menarik pajak dan retribusi daerah yang relatif besar kepada masyarakat.

Di samping yang disebutkan di atas adalah perlunya menjadikan daerah Provinsi Jawa Timur sebagai daerah yang menarik untuk berinvestasi. Strategi yang dapat ditempuh dalam rangka menarik investasi ke daerah, pertama, memberikan fasilitas kemudahan di bidang permodalan dan perijinan untuk kegiatan industri, kedua, menjamin kontinuitas bahan suplai baku industri, ketiga, menjamin keamanan bagi pengusaha yang berinvestasi di daerah, keempat, di bidang perpajakan memberikan tax holiday bagi industri yang baru tumbuh di daerah baik itu industri yang murni dikelola oleh pihak swasta maupun usaha yang dikelola oleh perusahaan daerah, misalnya untuk tidak mengenakan pajak dan retribusi daerah dalam kurun waktu satu atau dua tahun atau sampai industri atau usaha tersebut telah benar-benar dapat beroperasi secara normal.

\section{KESIMPULAN, IMPLIKASI, SARAN, DAN BATASAN}

Berdasarkan uraian di atas, maka hasil penelitian dapat disimpulkan sebagai berikut: Tidak ada yang signifikan dari hasil regresi. Ini berarti bahwa peningkatan atau penurunan pada jumlah produk domestik regional bruto tidak memi-liki efek pada pendapatan dari Provinsi Jawa Timur.

Dari kesimpulan di atas, beberapa hal yang dapat ditempuh dalam perencanaan penerimaan pendapatan asli daerah di Provinsi Jawa Timur yakni :

Dalam upaya mengurangi ketergantungan pada daerah pemerintah pusat dalam hal keuangan daerah untuk pembiayaan pembangunan, halhal menarik yang bisa dilakukan adalah adanya sebuah stimulator aktor untuk meningkatkan pendapatan, misalnya dengan membentuk badan usaha atau perusahaan lokal yang mengelola sistem bisnis yang dimungkinkan oleh Provinsi Jawa Timur Pemerintah diandalkan sebagai sumber pendapatan.

Pengeluaran untuk anggaran pemerintah untuk membangun sarana dan prasarana infrastruktur dasar harus jauh ditambah besarnya. Sarana dan prasarana yang baik sangat diperlukan untuk pengembangan dunia usaha yang akan berdampak pada pertumbuhan ekonomi. Dengan perkembangan pembangunan ekonomi daerah, diharapkan untuk meningkatkan produksi dan dana akhirnya menaikkan dari masyarakat dalam bentuk pajak dan retribusi akan dikembangkan. Jadi akan ada korelasi antara peningkatan pertumbuhan ekonomi dan pendapatan daerah. 


\section{DAFTAR PUSTAKA}

Anonim. (2015).Buku Data Dinamis Provinsi Jawa Timur Semester I tahun 2015. Tanpa penerbit

Ardiyanto, Danis. (2012). Analisa Keterkaitan Pengeluaran Pemerintah Dan Produk Domestik Bruto Di Indonesia : Pendekatan Vector Error Correction Model(Vecm). Jurnal Ilmiah Fakultas Ekonomi Universitas Brawijaya Malang. www.jimfeb.ub.ac.id. Diakses pada 30 September 2015

Badan Pusat Statistik Indonesia. (2015). Boklet seluruh provinsi di Indonesia. www.bps.go.id. Data Pertumbuhan Ekonomi tahun 2015. Diakses pada 30 September 2015

Boediono. (2012). Teori Pertumbuhan Ekonomi, Edisi Pertama. Yogyakarta: BPFE

Direktorat Jendral Perimbangan. (2015). Keuangan Kementrian seluruh provinsi di Indonesia. -www.djpk.kemenkeu.go.id. Data Daerah Anggaran Provinsi Jawa Timur tahun 2006-2014. Diakses pada 30 september 2015

Djojohadikusumo, Sumitro. (1994). Dasar Teori Ekonomi Pertumbuhan dan Ekonomi Pembangunan. Jakarta: LP3ES

Fisanti Atni. (2013). Analisis Faktor -Faktor Yang Mempengaruhi Pendapatan Asli Daerah (Pad) Di Kabupaten Rokan Hulu. Jurnal Penelitian Fakultas Ekonomi Universitas Pengaraian.www.e-journal.upp.ac.id. Diakses pada 30 September 2015

Gujarati, Damodar. (2012). Dasar- dasar Ekonometrika, buku 1 dan 2 edisi 5. Jakarta Salemba Empat Insukindro, 1992. Insukindro Error Correction Model. Jogjakarta: BPFE UGM..

Jaya, I Putu Ngurah Panji Kartika Dan Dwirandra, A.A.N.B. 2014. Pengaruh Pendapatan Asli Daerah Pada Belanja Modal Dengan Pertumbuhan Ekonomi Sebagai Variabel Pemoderasi. Jurnal Akuntansi Universitas Udayana. www.ojs.unud.ac.id. Diakses pada 30 September 2015.

Khusaini, Mohammad. (2006). Ekonomi Publik Desentralisasi Fiskal dan Pembangunan Daerah. Malang; Badan Penerbit Fakultas Ekonomi Universitas Brawijaya.Malang : BPFE Universitas Brawijaya

Peraturan Daerah Nomor 14 Tahun 2014 tentang APBD Provinsi Jawa Timur 2015.

Putro, Nugroho Suratno. (2012). Pengaruh Pertumbuhan Ekonomi, Pendapatan Asli DaerahDan Dana Alokasi Umum Terhadap Pengalokasian AnggaranBelanja Modal ( $S$ tudy Kasus Pada Kabupaten/Kota DiProvinsi Jawa Tengah). Jurnal ilmiah Fakultas Ekonomi Universitas.Diponogoro.www.Eprints.undip .ac.id. Diakses pada 30 September 2015.

Undang-undang No 32 tahun 2004 pada Bab III Mengenai Pembagian Urusan Pemerintahan Penyelenggaraan Kewenangan Daerah. -www.kpu.go.id. Diakses pada 30 September 2015.

Undang-Undang No 33 Tahun 2004 Mengenai Pendapatan Asli Daerah. www.djlpe.go.id. Diakses pada 30 
September 2015.

Sitaniapessy, Harry A.P. (2013).

Pengaruh Pengeluaran Pemerintah

Terhadap Pdrb Dan PAD. Jurnal

Economia, Volume 9. www.-

journal.uny.ac.id. Diakses pada 30

September 2015.

Sugiyono. (2011). Metode Penelitian

Kuantitatif Kualitatif Dan $R \& D$.

Bandung: Alfabeta

Sodik, Jamzani. (2007). Pengelua-

ran Pemerintah Dan Pertumbuhan

Ekonomi Regional: Studi Kasus

Data Panel di Indonesia. Jurnal

Ekonomi Pembangunan vol12.

www.jurnal.uii.ac.id Diakses pada

30 September 2015.

Syafrizal (2008). Ekonomi Regional Teori dan Aplikasi. Padang : Badoese Media

Yulianita, Anna. (2008). Analisis

Sektor Unggulan Dan Pengeluaran

Pemerintah Di Kabupaten Organ

Komering Ilir. www.academia.edu.

Diakses pada 30 September 2015. 